\title{
Innovative Technology for Multifunctionalization of Cotton Fabric through Cellulase Biotreatment, Reactive Dyeing and Easy Care Finishing
}

\author{
A. Hebeish, M. M. Kamel, H. M. Helmy ${ }^{*}$ and N. S. El Hawary \\ Textile Division, National Research Centre, Cairo, Egypt.
}

\begin{abstract}
T NNOVATIVE technology for preparation of multifunctionalized 1 cotton fabrics with high technical performance was established. The innovation entailed the following consecutive sequence: cotton fabrics were subjected to cellulase biotreatment followed by reactive dyeing then easy care finishing treatment. $\mathrm{pH}$ was adjusted at 7 before commencing dyeing and finishing. No washing or drying was involved in the sequence. The so obtained fabrics displayed high technical performance as monitored by color strength, wrinkle recovery angle, retained strength in addition to softness and smoothness. Anchoring the enzyme to the cotton fabric ought to be taken as one of the reasons accounting for such high performance. It is believed that the enzyme protein molecules are fixed and immobilized within the molecules structure of cotton via their attachment to the cellulose hydroxyls by the finish molecules. The latter acts as bridges connecting the protein molecules of the enzyme with the cellulose macromolecules of the cotton fabric.
\end{abstract}

Keywords: Reactive dyes, Cotton Fabrics, Cellulase enzyme and Crosslinking .

Over the last three decades, new processing techniques based on harnessing of biotechnology in different disciplines of textile industry have been adopted. Techniques based on biotechnology using enzymes are advantageous for the following reasons: mild treatment conditions, replacing harsh chemicals, specificity of action, safe and easy to control, environmentally friendly, biodegradable, and are also economical ${ }^{(1-3)}$. There are continuous efforts to replace harsh chemicals with enzymes in textile processing. Cellulase is a commonly used enzyme for processes such as bio-preparation, bio-finishing, biopolishing and softening of cellulosic substrates ${ }^{(4-6)}$.

Current research is undertaken with a view to establish an eco-friendly technique for multifunctionalization of cotton fabric. Water and energy conservations are featured to address quality of the environment. Three processes, viz., cellulase biotreatment, reactive dyeing and easy care finishing, are run in a consecutive sequence without involvement of washing and drying steps in-between; the devised technique is based on wet-wet procedures.

"Corresponding author. Tel.: +20 122217 4602; Fax: +20 233363261 .

E-mail address: hany_helmy2001@yahoo.com 


\section{Materials}

\section{Experimental}

Fabric

Plain weave (1/1) scoured and bleached cotton fabrics $\left(130 \mathrm{~g} / \mathrm{m}^{2}\right)$ were supplied by El-Amerya Company for Fine Spinning and Weaving, Alexandria, Egypt.

Enzymes

Cellusoft Conc. L (with an activity 750 EGU/g) was supplied by NovoNordisk- Denmark; imported by Port Said Company, Port Said, Egypt.

Dyes

Two different commercial reactive dyes were used:

- Levafix Brilliant Red E-RN, CI Reactive Red 242, (a mono functional reactive dye).

- Procion Yellow H-E3B, CI Reactive yellow120, (bi-functional reactive dye).

Chemicals

Acetic acid, sodium carbonate, citric acid (CA), 1,2,3,4 butantetracarboxylic acid (BTCA), sodium hypophosphite $\left(\mathrm{NaH}_{2} \mathrm{PO}_{2}\right)$ and magnesium chloride hexahydrate $\left(\mathrm{MgCl}_{2} \cdot 6 \mathrm{H}_{2} \mathrm{O}\right)$, were of laboratory grade chemicals. Finishing agent GL300 (based on dimethyldihydroxyethlene urea DMDHEU) was of technical grade.

\section{Methods}

Wet-wet procedures were established to affect cellulase biotreatment, reactive dyeing and easy care finishing. No washing or drying was involved in this consecutive sequence. Described below are the experimental techniques adopted in each of these treatments.

\section{Enzymatic treatment}

Cotton fabric was treated with aqueous solution containing the cellulase enzyme ( $5 \%$, owf) at $\mathrm{pH} 5$ using acetate buffer. The treatment was carried out at $40^{\circ} \mathrm{C}$ for $30 \mathrm{~min}$ using a material to liquor ratio $1: 50$. When the time allowed was over, the temperature was raised to $100^{\circ} \mathrm{C}$ for $10 \mathrm{~min}$ to stop the enzyme action by denaturation. At this end, $\mathrm{pH}$ of the biotreatment medium was adjusted at $\mathrm{pH} 7$.

\section{Reactive dyeing}

The pre-biotreated cotton fabric samples were dyed using Thermostatic Atlas Rotadyer- with Levafix B Red E-RN, (a mono functional reactive dye) and Procion yellow H-E3B, CI Reactive yellow120, (bi-functional reactive dye), (2\% each, owf), keeping a material to liquor ratio1:20. Fabric samples were introduced into cups of Thermostatic Atlas Rotadyer followed by, addition of the dye solution and agitation for $25 \mathrm{~min}$ at $40^{\circ} \mathrm{C}$. Sodium chloride $(50 \mathrm{~g} / \mathrm{l})$ was then added and agitation continued for $40 \mathrm{~min}$. At this end, sodium carbonate $(20 \mathrm{~g} / \mathrm{l})$ was added, the temperature raised to $60^{\circ} \mathrm{C}$ and dyeing continued for $60 \mathrm{~min}$. After being cooled down, the dyeing medium was adjusted at $\mathrm{pH} 7$.

Egypt. J. Chem. 56, No. 5,6 (2013) 
Crosslinking of pre-biotreated and dyed cotton fabric

Crosslinking to impart ease of care characteristics to cotton fabrics that were pre-treated with the enzyme followed by reactive dyeing was conducted using three finishes. The latter included DMDHEU at a concentration of $50 \mathrm{~g} / \mathrm{l}$ using $\mathrm{MgCl}_{2} \cdot 6 \mathrm{H}_{2} \mathrm{O}(10 \mathrm{~g} / \mathrm{l})$ as a catalyst, citric acid at a concentration of $(50 \mathrm{~g} / \mathrm{l}) \mathrm{using}$ sodium hypophosphite $\left(\mathrm{NaH}_{2} \mathrm{PO}_{2}\right)$ at a concentration of $(30 \mathrm{~g} / \mathrm{l})$ as a catalyst and 1,2,3,4-butantetracarboxylic acid $(50 \mathrm{~g} / \mathrm{l})$ using sodium hypophosphite $\left(\mathrm{NaH}_{2} \mathrm{PO}_{2}\right)$ at a concentration of $(30 \mathrm{~g} / \mathrm{l})$ as a catalyst. The catalyst was added to the aqueous bath of the finish just before application. The finishing treatment was carried out according to the conventional pad-dry-cure method. Fabrics loading the reactive dye and cellulase solutions were padded twice (two dips and two nips) in the finishing solution containing the catalyst to a wet pick of $120 \%$ then dried at $85^{\circ} \mathrm{C}$ for $3 \mathrm{~min}$. The fabrics were then cured at $160^{\circ} \mathrm{C}$ for $3 \mathrm{~min}$ in an oven with circulated air.

Testing

Tensile strength and elongation at break were monitored by the strip method according to ASTM method ${ }^{(7)}$.

The color strength of dyed samples was evaluated by light reflectance technique using the Perkin-Elmer, UV/V Spectrophotometer (Model, Lambda 3B) using the following Kubelka-Munk equation:

$$
K / S=\frac{(1-R)}{2 R}-\frac{(1-R o)}{2 R o}
$$

where:

$\mathrm{R}=$ Decimal fraction of the reflectance of the dyed fabric.

$\mathrm{R}_{0}=$ Decimal fraction of the reflectance of the undyed fabric.

$\mathrm{K}=$ Absorption coefficient.

$\mathrm{S}=$ Scattering coefficient.

Wrinkle recovery angle (WRA) was measured as per AATCC test method $66-1990^{(8)}$

The dyed samples were tested for fastness to washing, to acid and alkaline perspiration, to dry and wet rubbing and to light fastness according to AATCC standard methods. The effect on the color of the test specimen was expressed and defined by reference to grey scale for staining and color change ${ }^{(9-12)}$.

Scanning Electron Microscopy (SEM)

Surface characterization of selected fabric samples before and after being processed as described above were studied using a scanning electron probe microanalyzer (JXA-840A), Japan. The specimens in the form of films were mounted on the specimen stabs and coated with thin film of gold by the sputtering method. The micrographs were taken at magnification of 2000 using (KV) accelerating voltage. 


\section{Results and Discussion}

\section{Multifunctionalization of cotton fabric}

Multifunctionalization of cotton fabric was affected in the current work through enzymatic biotreatment, reactive dyeing and easy care finishing. The biotreatment was practiced using cellulase enzyme whereas the reactive dyeing was conducted using mono and bifunctional dyes. On the other hand, easy care finishing was conducted using three finishes, namely, DMDHEU, CA and BTCA. The biotreatment, dyeing and finishing were carried out in wet - wet procedures without washing or drying inbetween. Fabrics so processed were monitored for color strength, wrinkle recovery angle and tensile strength. Results obtained are summarized in Table 1.

TABLE 1. Effect of multifunctionalization of cotton fabric by cellulose enzyme, reactive dyeing, and easy care finishing using DMDHEU, CA, or BTCA on some of its properties

\begin{tabular}{|c|c|c|c|c|c|c|c|c|}
\hline \multicolumn{3}{|c|}{$\begin{array}{l}\text { Dyed fabric } \\
\quad \text { (Blank) }\end{array}$} & \multicolumn{2}{|c|}{$\begin{array}{l}\text { Fabric treated } \\
\text { with cellulase } \\
\text { enzyme then } \\
\text { dyed }\end{array}$} & \multicolumn{2}{|c|}{$\begin{array}{l}\text { Fabric treated with } \\
\text { cellulase enzyme, } \\
\text { dyed then finished } \\
\text { using DMDHEU }\end{array}$} & \multicolumn{2}{|c|}{$\begin{array}{l}\text { Fabric dyed then } \\
\text { finished using } \\
\text { DMDHEU without } \\
\text { enzyme treatment }\end{array}$} \\
\hline : & 哥 & 苞 & 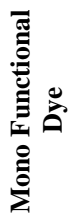 & 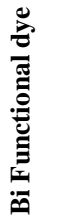 & 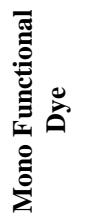 & 氙 & 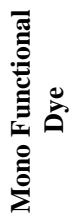 & 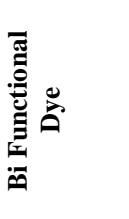 \\
\hline $\begin{array}{l}\text { TS } \\
(\mathrm{Kg})\end{array}$ & 63 & 63 & 57 & 57 & 54 & 54 & 55 & 55 \\
\hline $\mathrm{K} / \mathrm{S}$ & 4.00 & 6.06 & 7.80 & 11.98 & 7.90 & 12 & 6 & 8.06 \\
\hline WRA & 180 & 180 & 191 & 191 & 265 & 265 & 268 & 268 \\
\hline & & & & & \multicolumn{2}{|c|}{$\begin{array}{c}\text { Fabric treated with } \\
\text { cellulase enzyme, } \\
\text { dyed then finished } \\
\text { using CA }\end{array}$} & \multicolumn{2}{|c|}{$\begin{array}{c}\text { Fabric dyed then } \\
\text { finished using CA } \\
\text { without enzyme } \\
\text { treatment }\end{array}$} \\
\hline $\begin{array}{l}\text { TS } \\
(\mathbf{K g})\end{array}$ & & & & & 52 & 52 & 53 & 53 \\
\hline $\mathrm{K} / \mathrm{S}$ & & & & & 7.55 & 11.88 & 5.98 & 8 \\
\hline \multirow[t]{2}{*}{ WRA } & & & & & 217 & 217 & 220 & 220 \\
\hline & & & & & \multicolumn{2}{|c|}{$\begin{array}{l}\text { Fabric treated with } \\
\text { cellulase enzyme, } \\
\text { dyed then finished } \\
\text { using BTCA }\end{array}$} & \multicolumn{2}{|c|}{$\begin{array}{l}\text { Fabric dyed then } \\
\text { finished using } \\
\text { BTCA without } \\
\text { enzyme treatment }\end{array}$} \\
\hline $\begin{array}{l}\text { TS } \\
(\mathrm{Kg})\end{array}$ & & & & & 56 & 56 & 55 & 55 \\
\hline$K / S$ & & & & & 7.95 & 11.97 & 7.66 & 11.20 \\
\hline WRA & & & & & 269 & 269 & 273 & 273 \\
\hline
\end{tabular}

- (DMDHEU) Dimethyloldihydroxyethelen urea - (K/S) Color strength

- (CA) Citric acid

- (TS) Tensile strength (Kg)

- (BTCA) Butanetetracarboxylic acid

- (WRA) Wrinkle recovery angel

Egypt. J. Chem. 56, No. 5,6 (2013) 
It is clear (Table1) that biotreatment prior to reactive dyeing is accompanied by significant enhancement in color strength $(\mathrm{K} / \mathrm{S})$. The K/S increases from 4 to 7.8 and from 6.06 to 11.98 upon using monofunctional dye and bifunctional dye, respectively. Such increase in K/S is a direct consequence of the action of cellulase enzyme on the structure of cotton cellulose of the fabric. The cellulase enzyme converts the cotton structure to a more accessible textile substrate which is much more amenable to the dye, beside its biopolishing effect which plays a key role in reflectance - based measurements of the color on the fabric. Differences in K/S between the two reactive dyes used are a manifestation of the number of reactive functional groups in the dye molecules. As expected, the bifunctional dye produces higher K/S values than does the monofunctional dye by virtue of the double reactivity of the former. Alkaline hydrolysis of one reactive group in the bifunctional dye converts it monofunctional reactive dye in contrast with reactive dye containing one reactive group which is converted to the inactivated form and most probably behaves like a direct dye.

It is further noted that the cotton fabric exhibits a loss in tensile strength of $9.5 \%$ owing to biodegradation of cotton cellulose by the cellulase enzyme. Nevertheless, chemical degradation which may occur by alkaline oxidation in presence of atmospheric and occluded oxygen cannot be ruled out.

When the enzymatically treated and dyed cotton fabrics were subjected to easy care finishing treatment using DMDHEU, the fabrics retain their K/S values with a good tendency of the latter to display higher values especially with the monofunctional dye. Smoothness of the fabric surfaces through stabilization of the cotton structure by durable press finishing in addition to the biopolishing caused by the enzyme may account for this. It is rather possible that the higher color strength of the multifunctionalized cotton fabric is due to extra color imparted to the fabric through reaction of anchored (immobilized) enzyme protein macromolecule with the reactive dye. Needless to say that with its proteinic nature, this anchored enzyme is susceptible towards reaction with the reactive dye. It is understandable that anchoring to and, therefore, immobilization of the enzyme macromolecule on the fabric occurs through reaction of the crosslinking agent with both the cotton fabric and the enzyme ${ }^{(13-16)}$.

Results of Table 1 reveal also that while these fabrics lose only $14.3 \%$ of their tensile strength as a result of the finishing treatment using DMDHEU, they enjoy WRA with values which place these fabrics in wash-and-wear category.

Table 1 discloses that replacing DMDHEU as a durable press finish with other finishes, namely CA and BTCA brings about fabrics with very comparable color strength, tensile strength and wrinkle recovery angle. Considering these results together with the above corresponding results, it may be concluded that multifunctionalized cotton fabrics could be achieved through biotreatment using cellulase enzyme, reactive dyeing and durable press finishing. These fabrics acquire the color, the smooth and soft hand, the wrinkle resistance, meanwhile they retain more than $85 \%$ of their strength. They, indeed, display high textile

Egypt. J. Chem. 56, No. 5,6 (2013) 
performance while improving the quality of the environment. This is envisaged through: (a) water and energy conservations by omitting the washing and drying steps, (b) using eco-friendly finishes which are free of formaldehyde and (c) the enzyme used is biodegradable. ${ }^{(17-20)}$

\section{Fastness properties}

Table 2 shows the fastness properties of enzymatically treated cotton fabrics that were dyed with reactive dyes then finished using three different crosslinking agents. The latter included dimethylol dihydroxyethylene urea (DMDHEU), citric acid (CA) and 1,2,3,4-butanetetracarboxylic acid (BTCA).

It is seen (Table 2) that the overall fastness properties are improved generally by biotreatment using cellulase enzyme. This improvement becomes much more significant by subjecting the biotreated and dyed fabric to easy care finishing using any of the three finishing agents under investigation but with the certainity that BTCA is the best.

TABLE 2. Fastness properties of enzymatically treated cotton fabrics using cellulase enzyme then dyed and finished using either DMDHEU, CA or BTCA.

\begin{tabular}{|c|c|c|c|c|c|c|c|c|c|c|}
\hline \multirow{2}{*}{ Cotton Fabric } & \multirow{2}{*}{\begin{tabular}{|c|}
$\begin{array}{c}\text { Dyestuff } \\
\text { (mono or }\end{array}$ \\
Bi- \\
functional)
\end{tabular}} & \multicolumn{2}{|c|}{ Crocking } & \multicolumn{2}{|c|}{\begin{tabular}{c|c|} 
Acidic \\
Perspiration \\
\end{tabular}} & \multicolumn{2}{|c|}{$\begin{array}{c}\text { Alkaline } \\
\text { Perspiration } \\
\end{array}$} & \multicolumn{2}{|c|}{$\begin{array}{l}\text { Washing } \\
\text { fastness }\end{array}$} & \multirow{2}{*}{$\begin{array}{c}\begin{array}{c}\text { Light } \\
\text { fastness }\end{array} \\
40 \mathrm{HR}\end{array}$} \\
\hline & & DRY & WET & ST.* & ST.** & ST.* & ST.** & ST.* & ST.** & \\
\hline \multirow{2}{*}{$\begin{array}{l}\text { Fabric dyed } \\
\text { only }\end{array}$} & Mono & $3-4$ & 2 & $2-3$ & 2 & $2-3$ & 2 & 2 & 2 & 2 \\
\hline & Bi- & $3-4$ & 3 & $2-3$ & $2-3$ & $2-3$ & 2 & 3 & $2-3$ & $3-4$ \\
\hline \multirow{2}{*}{$\begin{array}{l}\text { Treatment with } \\
\text { cellulase } \\
\text { enzyme then } \\
\text { reactive dyeing }\end{array}$} & Mono dye & $3-4$ & 2 & $2-3$ & 2 & 2 & $2-3$ & 3 & $2-3$ & $2-3$ \\
\hline & $\mathrm{Bi}-$ & $3-4$ & 3 & $2-3$ & 3 & $2-3$ & $2-3$ & $2-3$ & 3 & $3-4$ \\
\hline \multirow{2}{*}{$\begin{array}{l}\text { Treatment } \\
\text { with: } \\
\text { 1. Cellulase } \\
\text { enzyme } \\
\text { 2. Reactive } \\
\text { dyeing } \\
\text { 3. Dmdheu } \\
\end{array}$} & Mono dye & 4 & $3-4$ & 3 & $3-4$ & $3-4$ & 3 & 3 & 3 & 3 \\
\hline & $\begin{array}{c}\mathrm{Bi}- \\
\text { functional } \\
\text { dye }\end{array}$ & 4 & 4 & $3-4$ & $3-4$ & 3 & 3 & 4 & 4 & 4 \\
\hline \multirow{2}{*}{$\begin{array}{l}\text { Treatment } \\
\text { with: } \\
\text { 1. Cellulase } \\
\text { enzyme } \\
\text { 2. Reactive } \\
\text { dyeing } \\
\text { 3. Ca }\end{array}$} & Mono dye & $3-4$ & 3 & 3 & 3 & 3 & 3 & 3 & 3 & $3-4$ \\
\hline & $\mathrm{Bi}-$ & $3-4$ & 3 & 3 & 3 & 3 & 3 & 3 & 3 & $3-4$ \\
\hline \multirow[b]{2}{*}{$\begin{array}{l}\text { Treatment } \\
\text { with: } \\
\text { 1. Cellulase } \\
\text { enzyme } \\
\text { 2. Reactive } \\
\text { dyeing } \\
\text { 3. Btca }\end{array}$} & Mono dye & $3-4$ & $3-4$ & $3-4$ & 3 & 4 & $3-4$ & $3-4$ & 3 & $3-4$ \\
\hline & $\mathrm{Bi}-$ & $4-5$ & $3-4$ & 4 & $4-5$ & 4 & 4 & $4-5$ & $4-5$ & 5 \\
\hline
\end{tabular}

Egypt. J. Chem. 56, No. 5,6 (2013) 


\section{Scanning Electron Microscopy}

Changes in surface characteristics of the fibres of the cotton fabrics due to biotreatment using cellulase enzyme prior to reactive dyeing were investigated by making use of scanning electron microscopy (SEM). The effect of chemical finishing using three crosslinking agents namely; DMDHEU, CA and BTCA on surface characteristics of the enzymatically treated and dyed cotton fabrics was also studied. In the following, SEM images of the different samples examined are described.

Figure 1 represents SEM image of the fibres of the cotton fabric that has been dyed with Procion yellow H-E3B. This sample is referred to as the untreated cotton fabric. The SEM image shows surface irregularities of the normal cotton fibre.

Figure 2 shows SEM image of the fibres of the cotton fabric that have been enzymatically treated with cellulase enzyme then dyed with Procion yellow HE3B. As can be seen the enzymatic treatment smoothened the surface of the fibre with the certainity that the primary wall of the cotton fibre was the first target to the attack by the cellulase enzyme.

Figure 3 shows the SEM image of cotton fibre of a fabric that has been enzymatically treated with the cellulase enzyme, dyed with a reactive dye, namely, Procion yellow H-E3B, then subjected to chemical finishing using DMDHEU as a crosslinking agent. The image reflects smooth fibre surfaces by virtue of stabilizing the smoothening effect (i.e., biopolishing) brought about by the cellulase enzyme.

Figure 4 illustrates the SEM image of cotton fibre of a fabric that has been enzymatically treated with the cellulase enzyme then dyed with Procion yellow H-E3B, followed by chemical finishing using CA as a crosslinking agent. As evident, CA exerts less stabilization of the biopolished fibre surface (brought about by the cellulase enzyme) than DMDHEU.

Figure 5 shows that the use of BTCA as a crosslinking agent conserves and stabilizes the biopolished fibre surface in a mode similar to that of DMDHEU.

\section{Conclusion}

Innovative technique is developed for multifunctionalization of cotton fabric. The innovation is based on cellulase biotreatment, reactive dyeing and easy care finishing in a consecutive sequence without washing and drying in-between. It is a wet-wet procedure which would certainly conserve water and energy. This together with the use of eco-friendly ingredients would contribute positively to the quality of the environment. 


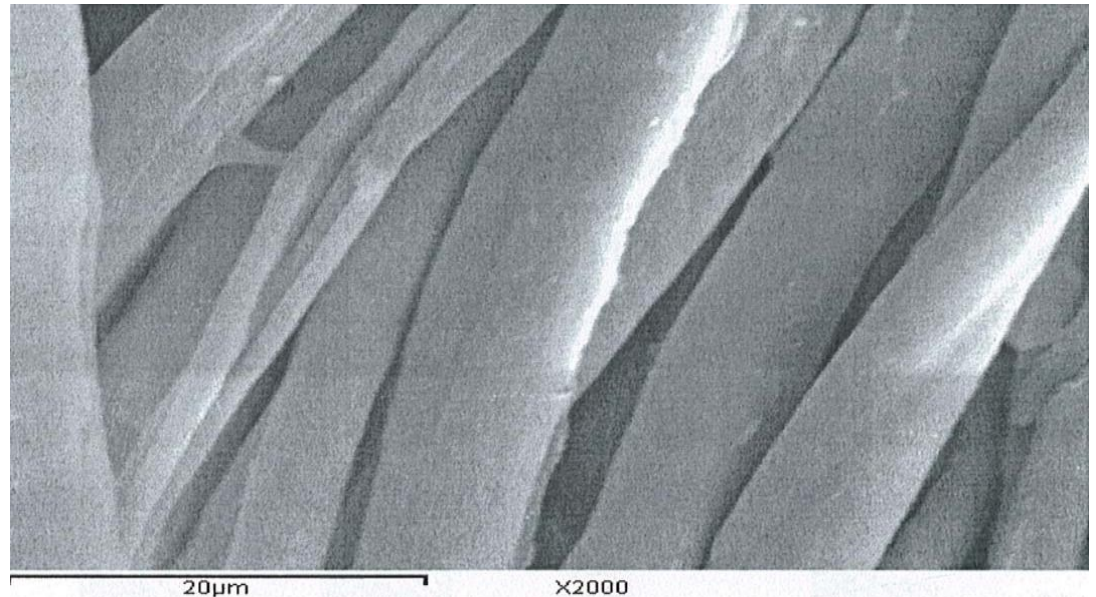

Fig. 1. SEM of untreated cotton fabric (fabric dyed with Procion yellow H-E3B dye only)

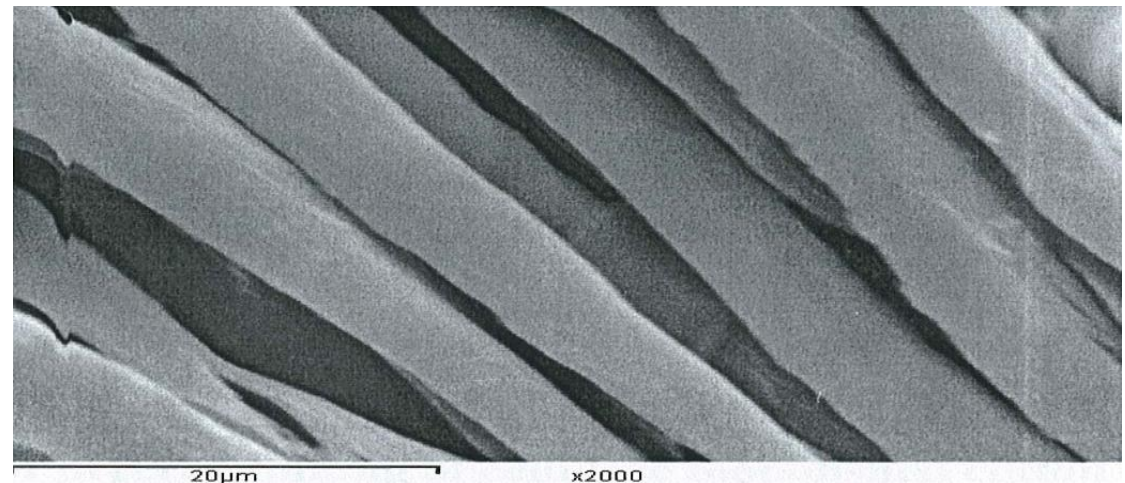

Fig. 2. SEM of cellulase treated cotton fabric, then dyed with Procion yellow H-E3B dye

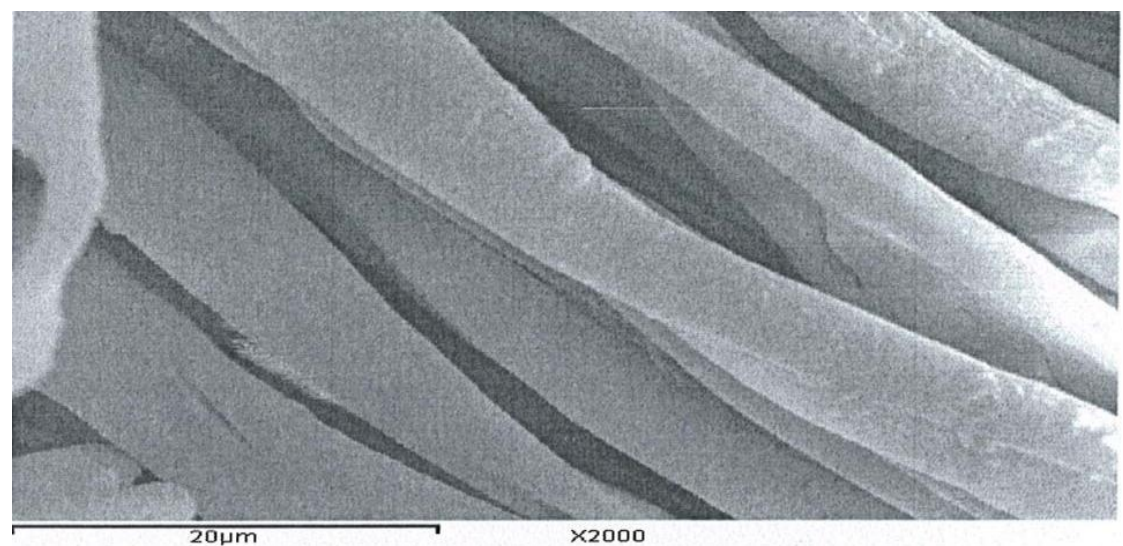

Fig. 3. SEM of fibers of a fabric enzymatically treated using cellulase then dyed with Procion yellow H-E3B dye, followed by finishing using DMDHEU.

Egypt. J. Chem. 56, No. 5,6 (2013) 


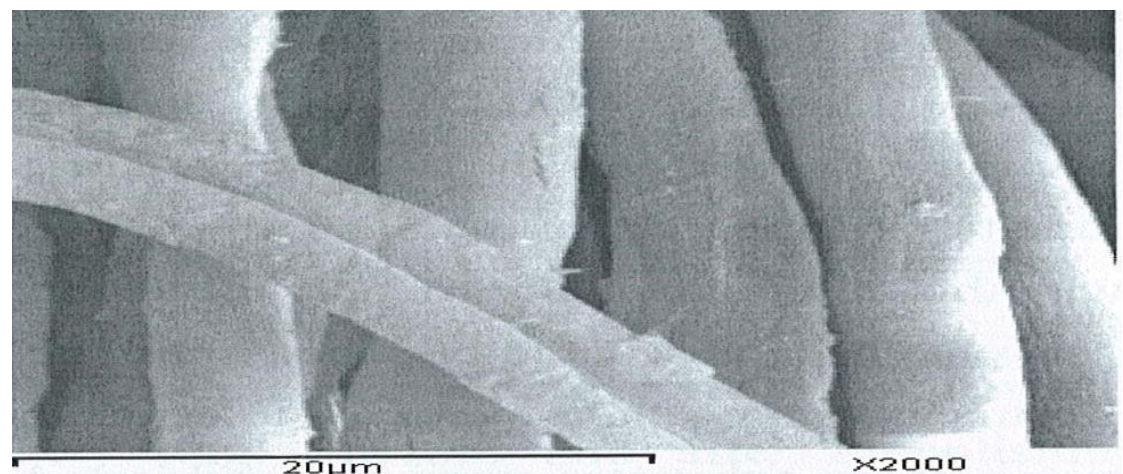

Fig. 4. SEM of fibers of a fabric enzymatically treated using cellulase then dyed with Procion yellow H-E3B dye, followed by finishing using CA.

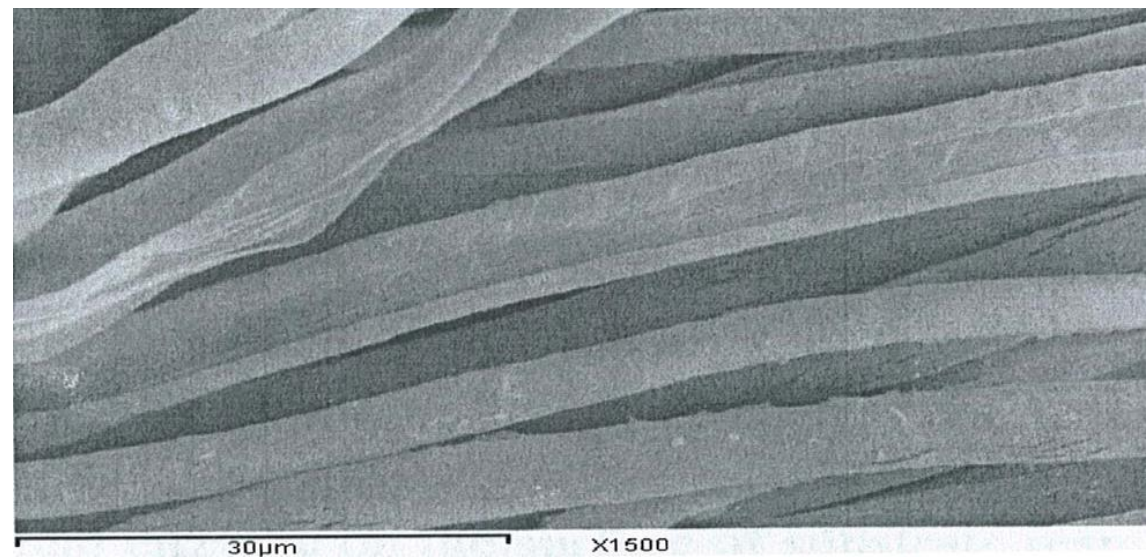

Fig. 5. SEM of fibers of cotton fabric enzymatically treated using cellulase then dyed with Procion yellow H-E3B dye, followed by finishing using BTCA.

\section{References}

1.Churi, R.Y. and Khadilkar, S.M, Enzyme based pretreatment for cotton goods. Colourage, 52 (7), 88-89 (2005).

2. Shukln, S.R., Jajpura L.R. and Damle A.J., Enzyme: the biocata-lysts for textile process. Colourage, $\mathbf{5 0}$ (11), 41-47(2003).

3. Tzanov, T., Andreaus, J., Guebitz, G. and Cavaco-Paulo, A., Protein interactions in enzymatic processes in textiles. Electronic Journal of Biotechnology, 6 (3), 8 (2003).

4. Cavaco-Paulo, A., Mechanism of cellulase action in textile processes. Carbohydrate Polymers, 37, 273-277 (1998).

5. Ibrahim, N.A., Fahmy, H.M., Hassan, T.M. and Mohamed, Z.E., Effect of cellulase treatment on the extent of post-finishing and dyeing of cotton fabrics. Journal of Materials Processing Technology, 160, 99-106 (2005).

Egypt. J. Chem. 56, No. 5,6 (2013) 
6. El-Sayed, H., El-Gabry, L. and Kantouch, F., Effect of biocarbonization of coarse wool on its dyeability. IJFTR, 35 (4), $330-336$, (2010).

7. ASTM, Standard Test Method for Breaking Load and Elongation of Textile Fabric, -D1682-94, American Society for Testing and Material, West Conshohocken, Pennsylvania, USA (1994).

8. AATCC, Wrinkle Recovery of Fabrics: Recovery Angle Method Standard Test Method 66, American Association of Textile Chemists and Colorists, NC, USA (1990).

9. AATCC, Technical Manual, Method 164 (1988) 68, 33-48(1993).

10. AATCC, Technical Manual, Method 15 (1989), 68, 30-32(1993).

11. AATCC, Technical Manual, Method 36 (1972), 68(1993).

12. AATCC, Technical Manual, Method 8 (1989), 68, 23-25(1993).

13. Hebeish, A. and Ibrahim, N., The impact of frontier sciences on textile industry. Colourage, 54 (4), 41-55(2007).

14. Ibrahima, N.A., EL-Badry, K., Eid, B.M. and Hassan, T.M., A new approach for biofinishing of cellulose-containing fabrics using acid cellulases. Carbohydrate Polymers, 83, 116-121 (2011).

15. Saravanan, D., Vasanthi, N.S. and Ramachandran, T., A review on influential behaviour of biopolishing on dyeability and certain physico-mechanical properties of cotton fabrics. Carbohydrate Polymers, 76, 1-7 (2009).

16. Hebeish, A., Hashem, M., Shaker, N., Ramadan, M., El-Sadek, B., Abdel Hady, M., Effect of post- and pre-crosslinking of cotton fabrics on the efficiency of biofinishing with cellulase enzyme. Carbohydrate Polymers, 78, 953-960 (2009).

17. Sreenath H.K., Shah, A.B., Yang, V.W., Gharia M.M. and Jeffries T.W., Enzymatic polishing of jute/cotton blended fabrics. Journal of Fermentation and Bioengineering, 81 (1), 18-20 (1996).

18. Hao, L., Wang, R., Liu, J. and Liu, R., The adsorptive and hydrolytic performance of cellulase on cationised cotton. Carbohydrate Polymers, 89, 171- 176 (2012).

19. Vankar, P.S. and Shanker, R., Ecofriendly ultrasonic natural dyeing of cotton fabric with enzyme pretreatments. Desalination, 230, 62-69 (2008).

20. Cavaco-Paulo, A., Mechanism of cellulase action in textile processes. Carbohydrate Polymers, 37 (3), 273-277 (1998). 


\title{
الخيارات العلمية المستخدمة في تطبيق المعالجة الحيوية بأستخدام

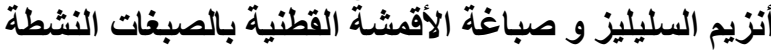 على حبيش ، منى كامل ، هانى حلمى و نانسى الهوارى شعبة النسيج ـ المركز القومى للبحوث - القاهرة - مصر.
}

\begin{abstract}
يتناول العمل الحالي ثلاثة طرق : وتستتد الطريقة الأولى على عملية من خطونين

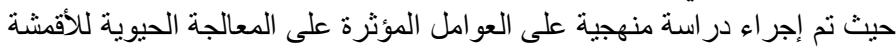

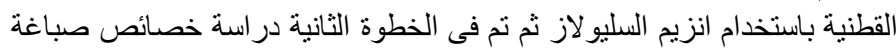

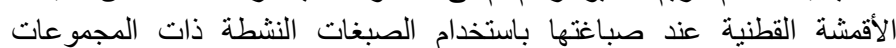

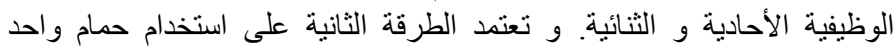

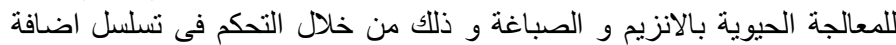

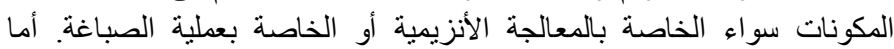

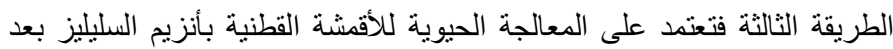

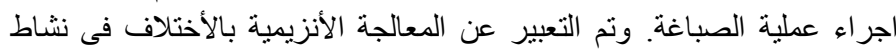

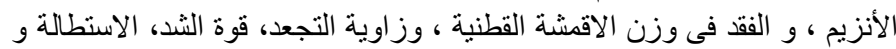

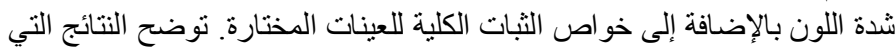

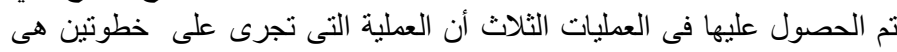

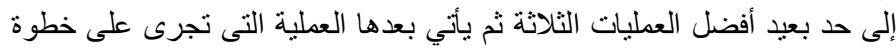

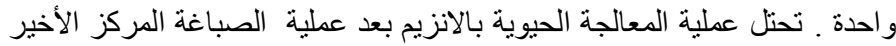

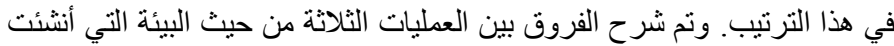

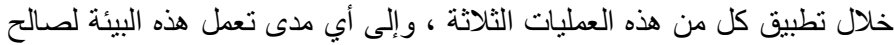
تفاعل الإنزيم أو الصبغة مع الأقمشة القطنية .
\end{abstract}

